JOURNAL OF SECURITY AND SUSTAINABILITY ISSUES

ISSN 2029-7017 print/ISSN 2029-7025 online

2019 September Volume 9 Number 1

http://doi.org/10.9770/jssi.2019.9.1(17)

Scopus

\title{
THREATS TO SUSTAINABLE DEVELOPMENT DUE TO INCREASE OF GREENHOUSE GAS EMISSIONS IN A KEY SECTOR
}

\author{
Madina Amangeldinovna Aitkazina ${ }^{1}$, Ermek Nurmaganbet ${ }^{2}$, Samal Syrlybekkyzy ${ }^{3}$, \\ Symbat Koibakova $^{4}$, Ainur Erbulatovna Zhidebayeva ${ }^{5}$, M.Zh. Aubakirov ${ }^{6}$ \\ ${ }^{1}$ JSC "Narxoz University", Almaty, 050035, Kazakhstan \\ 2,3,4,5essenov University, Aktau, 130003, Kazakhstan \\ ${ }^{6}$ The Ministry of Education and Science of the Republic of Kazakhstan, Republican State Enterprise, \\ A. Baitursynov Kostanay State University, Kostanay, 110000, Kazakhstan \\ E-mails: 'aitkazina.m@mail.ru;'2yermek.nurmaganbet@yu.edu.kz; ${ }^{3}$ samal.syrlybekkyzy@yu.edu.kz;

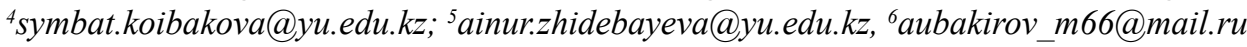

Received 11 November 2018; accepted 15 June 2019; published 30 September 2019

\begin{abstract}
This study is aimed to analyze the tendencies of agricultural pollution and their impact on the incidence rates of the rural population of the Republic of Kazakhstan. A retrospective assessment of statistical indicators of agricultural emissions of greenhouse gases and pesticide load, as well as a comparative analysis of the incidence rate ratios of the population of Kazakhstan and other countries, are chosen as the main research methods. The study shows that an increase in greenhouse gas emissions from livestock and crop production, the introduction of pesticides and other chemical plant protection products lead to an increase in morbidity and mortality. The high growth rates of registered congenital anomalies among the rural population, as well as the incidence of cerebrovascular diseases and asthma, are especially disturbing. After studying and summarizing expert opinions, two priority directions that could contribute to reducing the level of agricultural pollution in the Republic of Kazakhstan have been identified. Measures should be aimed at improving the mechanisms for the use of pesticides in crop production, as well as reducing greenhouse gas emissions in Kazakhstan's agriculture.
\end{abstract}

Keywords: $\mathrm{CO} 2$ emissions, agricultural pollution, environmental risks, agriculture, rural morbidity, mortality, environment

Reference to this paper should be made as follows: Aitkazina, M.A.; Ermek, N.; Syrlybekkyzy, S.; Koibakova, S.; Zhidebayeva, A.E.; Aubakirov, M.Zh. 2019. Threats to sustainable development due to increase of greenhouse gas emissions in a key sector, Journal of Security and Sustainability Issues 9(1): 227-240. http://doi.org/10.9770/jssi.2019.9.1(17)

JEL Classifications: Q52, Q59.

\section{Introduction}

The development of farming and agriculture means is the basis of people's lives in the modern world. Agriculture is the dominant component of the global economy, feeding the rapidly growing population of the planet. Agriculture takes $70 \%$ of the global freshwater withdrawal and reduces the natural habitat for $53 \%$ of endangered terrestrial species (Tanentzap et al., 2015).

Agriculture has been a natural process that did not damage the land for thousands of years. However, modern farming methods have changed the original ecosystem. Since the demand for food has increased, the environmental pollution caused by agricultural practice has increased in proportion to population growth.

Agricultural pollution is environmental pollution caused by the use of natural and chemical products for agriculture. This pollution is actually harmful to all living organisms which feed on crop and livestock products. 
Agricultural pollution is one of the reasons for the increase in the incidence and premature death of the population.

The problem of natural agricultural pollution is still relevant for the Republic of Kazakhstan. The active development of Kazakhstan's natural resources has led to enormous and often irreparable environmental damages. The main environmental problems in the country are caused either by the legacy of the Soviet times or by rapid economic development. The high energy intensity of the economy based on fossil fuels has a negative impact on the environment. Kazakhstan has an easily disturbed environment due to its geographical features, such as the predominance of semi-desert. Moreover, water scarcity and pollution also have a negative impact on public health and the economy. Air pollution, waste production, water scarcity and water pollution have an adverse effect on public health, the ecosystem, the environment and the economy (OECD, 2016a).

Addressing current environmental issues and climate change impact is of paramount importance in Kazakhstan, therefore, it is necessary to better understand these issues. Ospanova (2014) notes that the country's current environmental problems are the disposal and processing of industrial, municipal and toxic waste, access to water, its quality and shortage, air pollution, the Aral Sea situation, land degradation and desertification, degradation of the Caspian Sea ecosystem, oil spills, biodiversity loss, and low share of renewable energy sources.

Although air and water pollutions adversely affect agriculture, agricultural methods lead to environmental pollution.

Wasteful water use, overuse of pesticides and fertilizers in agriculture raise a serious concern. Problems of water quality and increased salinity content arise from the evaporation of irrigation and drainage effluents (FLERMONECA, 2015). Desertification, erosion, and overgrazing have significantly reduced the area of agricultural land (FLERMONECA, 2015). Much land was lost due to the fact that vast areas of the Kazakh prairie were plowed during the Khrushchev's agricultural project "Virgin Lands". Sixty percent of the Republic's pastures were at different stages of desertification by the mid-1990s.

Overgrazing is another problem of the Republic of Kazakhstan and other Central Asian countries. There are too many animals in a too small territory, which has led to desertification and soil erosion. According to some estimations, the restoration of used pastures and agricultural land will take from 10 to 50 years.

The above-mentioned problems prove that it is necessary to investigate more deeply the effects of agricultural pollution on living standards and to identify promising areas for improving environmental indicators in agriculture of the Republic of Kazakhstan.

\section{Literature Review}

The literature on the topic of this research is mainly focused on the conceptual problems of sustainable agriculture. According to Food and Agriculture Organization (FAO) (2018), sustainability means that agriculture provides a sustainable food supply, and also that its environmental impact, socio-economic conditions, and human health are recognized and taken into account in national development plans.

Global studies show that the agriculture of many countries of the world remains a significant contributor to the environment (Wenet al., 2017).

Most studies examine the level of agricultural pollution's impact on water quality. According to Wen, Schoups and van de Giesen (2017), agriculture is responsible for discharging a large number of agrochemicals, organic matter, drug residues, sediment, and salt drainage into reservoirs. Water pollution caused by this creates obvious risks to aquatic ecosystems, human health, and production activities (Mateo-Sagasta et al., 2015).

Poor management of wastewater and agricultural drainage creates serious problems with water quality in many 
parts of the world and exacerbates the global water crisis (Oetjen et al., 2018). Serio, Miglietta, Lamastra, Ficocelli, Intini, De Leo and De Donno (2018) consider that feces, slaughterhouse waste, etc. have tremendous sway with the quality of water resources.

Over the past 20 years, a pollutant has emerged in the form of veterinary drugs (antibiotics, vaccines and growth stimulants, such as hormones) that move through water from farms to ecosystems and drinking water sources (Boxall, 2012).

Many researchers agree that high levels of agricultural waste have a negative impact on various forms of aquatic life (Sato et al., 2013). For example, eutrophication caused by the accumulation of nutrients in lakes and coastal waters affects biodiversity and fisheries (Shin et al., 2015).

The studies by Seilkhan, Mizadinov, Mizadinov, and Kizdarbekova (2016) are devoted to studying the problems and connected with pastures and feeding grounds. Pasture degradation is a special environmental issue, faced by all Central Asian countries and countries of the Caucasus. This problem is important for the socio-economic welfare of local communities, as pastures are a strategic resource for economic development, especially in rural areas, providing environmental and food security (Robinson et al., 2017).

Bodemayer and Fabian (2015) consider that today degradation (desertification) has affected about one-third of the Earth's surface. The sharp deterioration in regional food security, poverty, and hunger of the population are the consequences of desertification and drought. Social, economic and political tensions caused by these consequences can escalate into various conflicts, impoverishment of people and intense land degradation (Gintzburger et al., 2005). The growing level of desertification threatens the world with a sharp increase in the number of people who have migrate in order to find a way to make a living and a place to live (Dörre \& Borchardt 2012).

Falling into drinking water pesticides, ammonia, heavy metals, fertilizers and oils from agricultural machinery and equipment create serious people's health problems (Chen, Huo, Dai, Ma, Xu, Huang 2018). For example, studies by Ahada and Suthar (2018) prove that the increase in the incidence of methemoglobinemia (blue baby syndrome) causing children death is the result of a high nitrate level in groundwater, especially in rural water systems.

A World Health Organization (WHO) study based on a systematic review of the literature, as well as research from more than 100 experts around the world, identified specific diseases that are affected by some well-known aspects of the environment (Prüss-Ustün et al., 2016). Experts identified two groups of diseases caused by the environmental state:

Group 1 - infectious and parasitic diseases. It includes respiratory infections, diarrheal disease, intestinal nematodes, parasitic diseases, HIV/AIDS, tuberculosis.

Group 2 - non-communicable diseases, such as cancer; mental, behavioral, and neurological disorders; diseases of the sense organs; cardiovascular diseases, respiratory diseases; renal failure; diseases of the musculoskeletal system; congenital anomaly.

Most researchers conclude that it is necessary to develop methodological approaches to the quantitative assessment of arid pastures and the degree of soil degradation (Menta et al., 2018). Alimaev (2008) believes that methods of land improvement and sustainable management of degraded pastures need to be improved.

Literature review shows that the improvement of environmental performance in agriculture is a common problem. It can be solved by enhancing the beneficial and reducing negative environmental impacts in order to ensure sustainable resource use (Shaaban et al. 2018). 


\section{Methods}

The purpose of this research is to study the types and dynamics of emissions in agriculture and to assess their impact on the population health of the Republic of Kazakhstan.

The study was conducted on the basis of statistical data of the FAO, the Committee on Statistics of the Republic of Kazakhstan, the WHO.

The first stage of the study includes a retrospective analysis of the statistical indicators for 2012-2016:

- Value-added of the agricultural industry in the country's total GDP, \%

- Pesticide consumption (kilograms per hectare of arable land)

- Agricultural emissions of carbon dioxide (thousand tons of $\mathrm{CO} 2$ equivalent);

- Agricultural methane emissions CH4 (thousand tons of CO2 equivalent);

- Agricultural emissions of nitrous oxide N2O (thousand tons of CO2 equivalent).

The second phase includes a comparative assessment of the agricultural pollution effects on public health. We used the following indicators:

- Mortality due to air pollution in the environment (per 100,000 people);

- The burden of environmental diseases (cases per 100,000 people).

\section{Results}

The Republic of Kazakhstan located in Central Asia is the ninth largest country in the world. The country shares borders with the Russian Federation in the north, with China in the east, with the Republics of Kyrgyzstan, Uzbekistan, and Turkmenistan in the south. In the west, it is washed by the Caspian Sea in the west and borders the Russian Federation. The country with a population of 16.7 million is one of the least densely populated countries.

The transition period to the market economy of the agricultural sector of Kazakhstan was difficult. Market reforms of land resources and agrarian property led to a significant transformation of the structure of agricultural production.

The country has sufficiently rich land resources. However, agricultural areas are affected by water scarcity and harsh climatic conditions. More than 90 million hectares of eroded and erosion-hazardous lands were registered in the Republic of Kazakhstan on January 1, 2016. The ongoing depletion of pastures leads to a decrease in the availability of water for livestock while changing weather conditions can cause flooding and early frosts which can lead to crop losses.

The depletion of water resources and an increase in temperature lead to an increase in aridity and a shift of the arid zone to the north. Significant changes can affect territories and land productivity. This can lead to the unprofitability of grain production in many areas.

The volume of greenhouse gas emissions from agriculture in the Republic of Kazakhstan continues to grow: their volume increased by $13.4 \%$ in $2012-2016$. The contribution of the agricultural sector to the total amount of greenhouse gas emissions in the Republic of Kazakhstan remains rather low and stable at the level of 9.3\%-9.5\% (Fig. 1). 


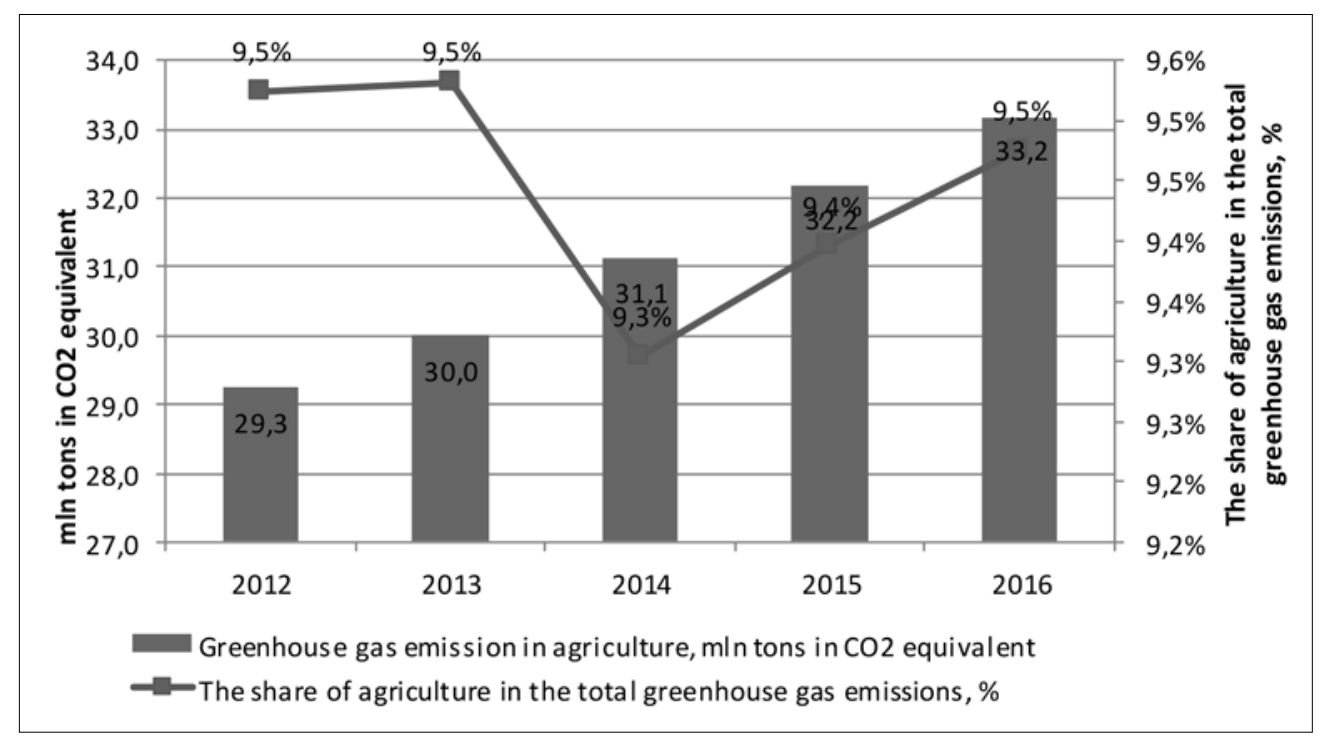

Figure 1. The contribution of the agricultural industry of the Republic of Kazakhstan to the total volume of greenhouse gases in 2012-2016.

Source: Compiled by autors.

During 2012-2016, agricultural emissions of methane in Kazakhstan decreased by 50.8\% from 23,955.6 thousand tons in $\mathrm{CO} 2$ equivalent in 2012 to 11,784.7 thousand tons in $\mathrm{CO} 2$ equivalent in 2016. At the same time, nitrous oxide emissions increased by 2\%: from 8,525.1 thousand tons in $\mathrm{CO} 2$ equivalent to 8,696.1 thousand tons in $\mathrm{CO} 2$ equivalent (Fig. 2).

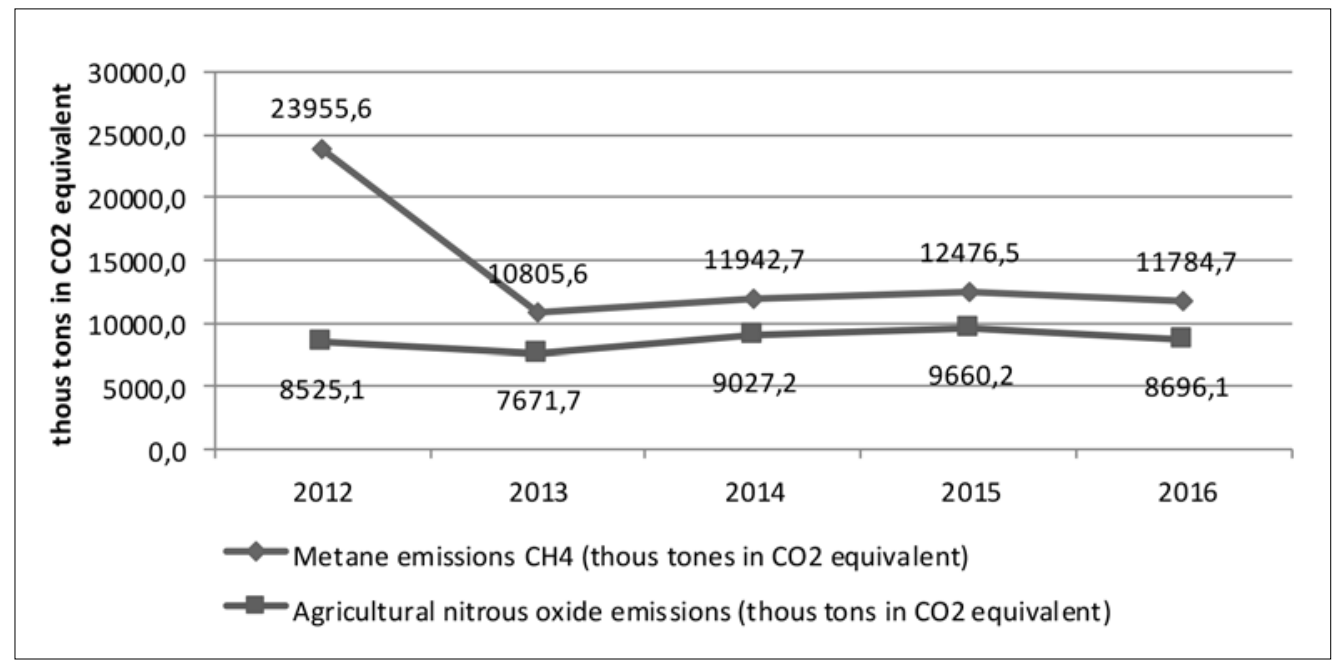

Figure 2. Dynamics of agricultural emissions of methane and nitrous oxide, thousand tons of $\mathrm{CO} 2$ equivalent.

Source: FAOSTAT, n. d.

Agricultural greenhouse gas emissions include emissions from livestock (enteric fermentation, manure collection, storage, and use systems) and crop production (mineral and organic fertilizers, plant waste, rice production, burning agricultural waste and the burning of savannas). The structure of emissions from the agricultural sector of the Republic of Kazakhstan in 2016 is shown in Fig. 3. 


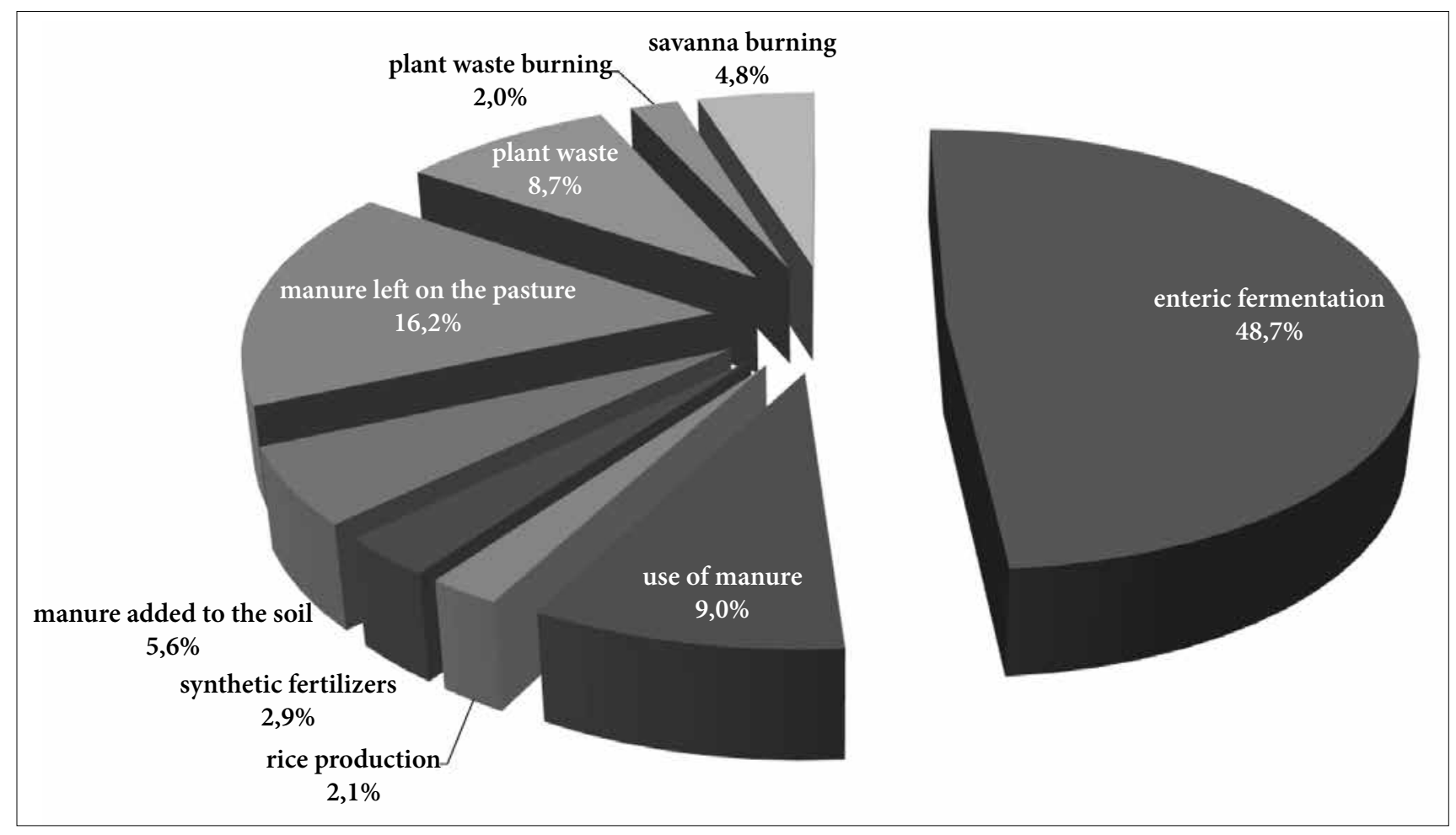

Figure 3. The structure of emissions in the agricultural sector of the Republic of Kazakhstan in 2016, \%.

Source: Compiled by autors.

Enteric fermentation and manure are the main sources of emissions, which account for almost $80 \%$ of total agricultural emissions.

Enteric fermentation is a source of methane emissions. Methane forms in the digestive process of ruminants. It also forms in the gastrointestinal tract of non-ruminant animals but in much smaller quantities. Emissions that are formed as a result of enteric fermentation largely depend on the quality of the feed. The more there is in the feed ration the proportion of poorly digestible roughage, the more methane is released into the atmosphere.

Animal fermentation emissions in the Republic of Kazakhstan amounted to 9,984.3 thousand tons of CO2 equivalent in 2016 and increased by $7.4 \%$ compared to 2012 .

Emissions of storage and distribution of manure in agriculture of Kazakhstan increased by 112.7 thousand tons in CO2 equivalent in 2012-2016 and reached 1,843.8 thousand tons in CO2 equivalent. Greenhouse gas (GHG) emissions from plant residues in the Republic of Kazakhstan increased by $42.4 \%$ in the last five years (Fig. 4). 


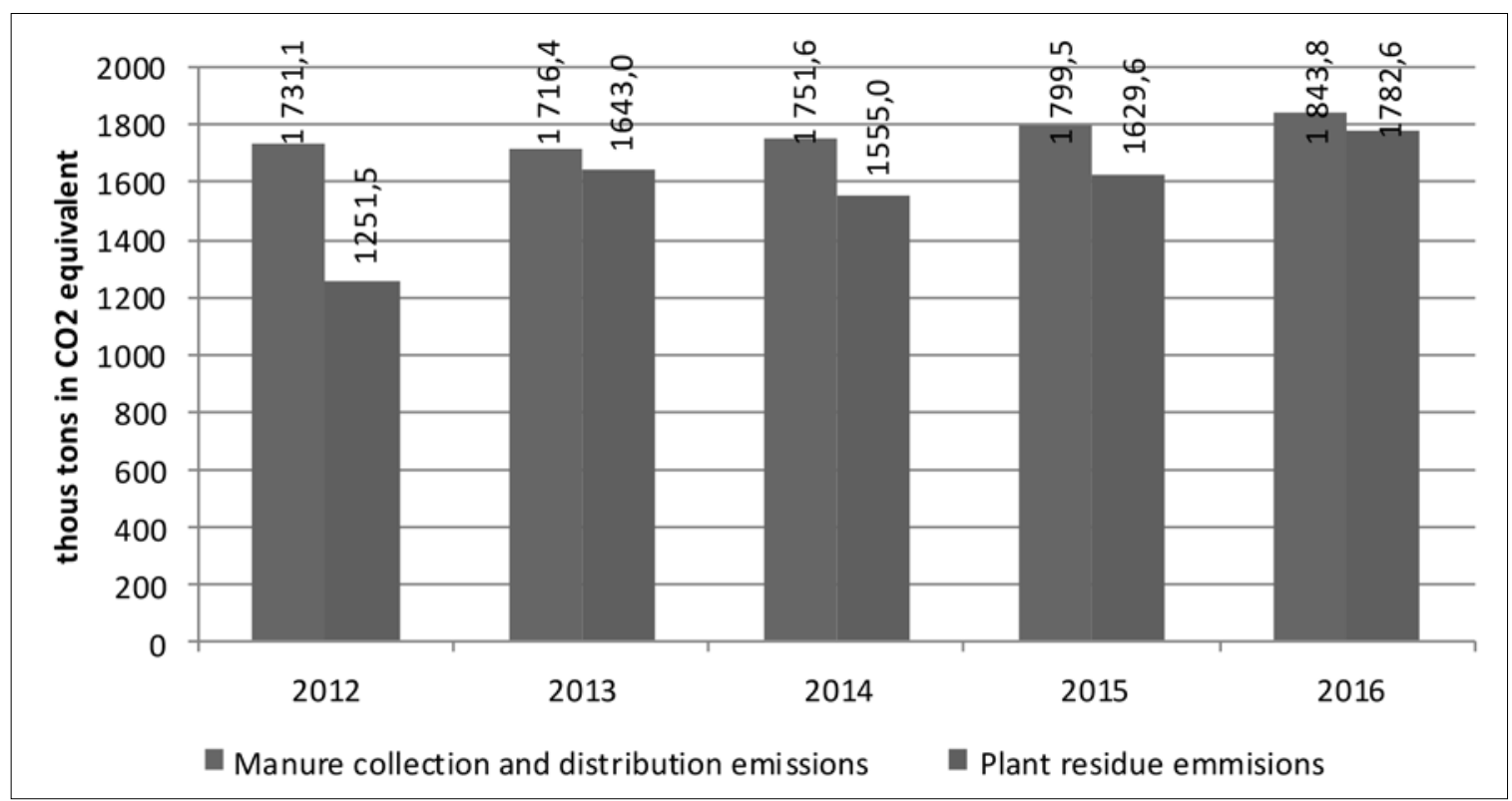

Figure 4. Dynamics of emissions from the storage and distribution systems of manure and plant residues in the Republic of Kazakhstan in 2012-2016.

Source: Compiled by autors.

The effects of perennial pesticide use (including obsolete and unsuitable pesticides and pesticides with persistent organic pollutant (POPs) properties) in agriculture are one of the most pressing problems of soil pollution in the Republic of Kazakhstan.

Despite the reduction of agricultural land areas, the use of plant protection chemicals has not changed and even increased. A specific application of pesticides per one ha of agricultural land went up almost by 1.7 times: from $0.29 \mathrm{~kg} / \mathrm{ha}$ in 2012 to $0.493 \mathrm{~kg} / \mathrm{ha}$ in 2016 (Fig. 5). The annual volume of applied pesticides varied from 10 to 11 thousand tons for the period.

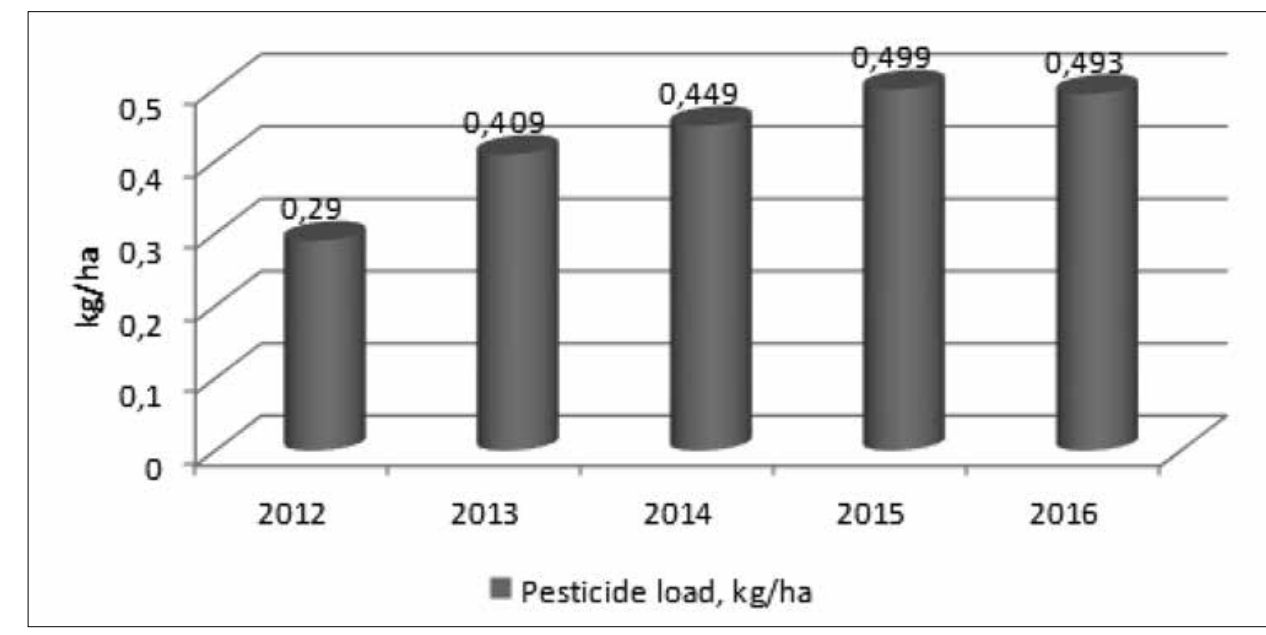

Figure 5. Dynamics of pesticide load of agricultural lands of the Republic of Kazakhstan in 2012-2016.

Source: Compiled by autors.

Nowadays, over 1.5 thousand tons of pesticides and their mixtures are stored in the warehouses of the Republic of Kazakhstan. At the same time, about $10 \%$ of them belong to the group of POPs (Analytical Environmental Agency "Greenwomen", 2018). 
Agricultural pollution has a significant impact on public health, the environment, crop yields, biodiversity, and the state of land and water resources.

The OECD study (2016b) showed that air pollution leads to 2,800 premature deaths and exceeds $\$ 1.3$ billion in healthcare expenditures in Kazakhstan.

According to WHO estimates, about $20 \%$ of deaths in Kazakhstan are related to environmental exposure. According to this indicator, Kazakhstan is inferior to Russia and Belarus (Fig. 6). This indicator is at the level of $11 \%-13 \%$ in countries with advanced economies. The mortality rate of the population due to the state of the environment in the Republic of Kazakhstan remains quite high at 224 cases per 1,000 population.

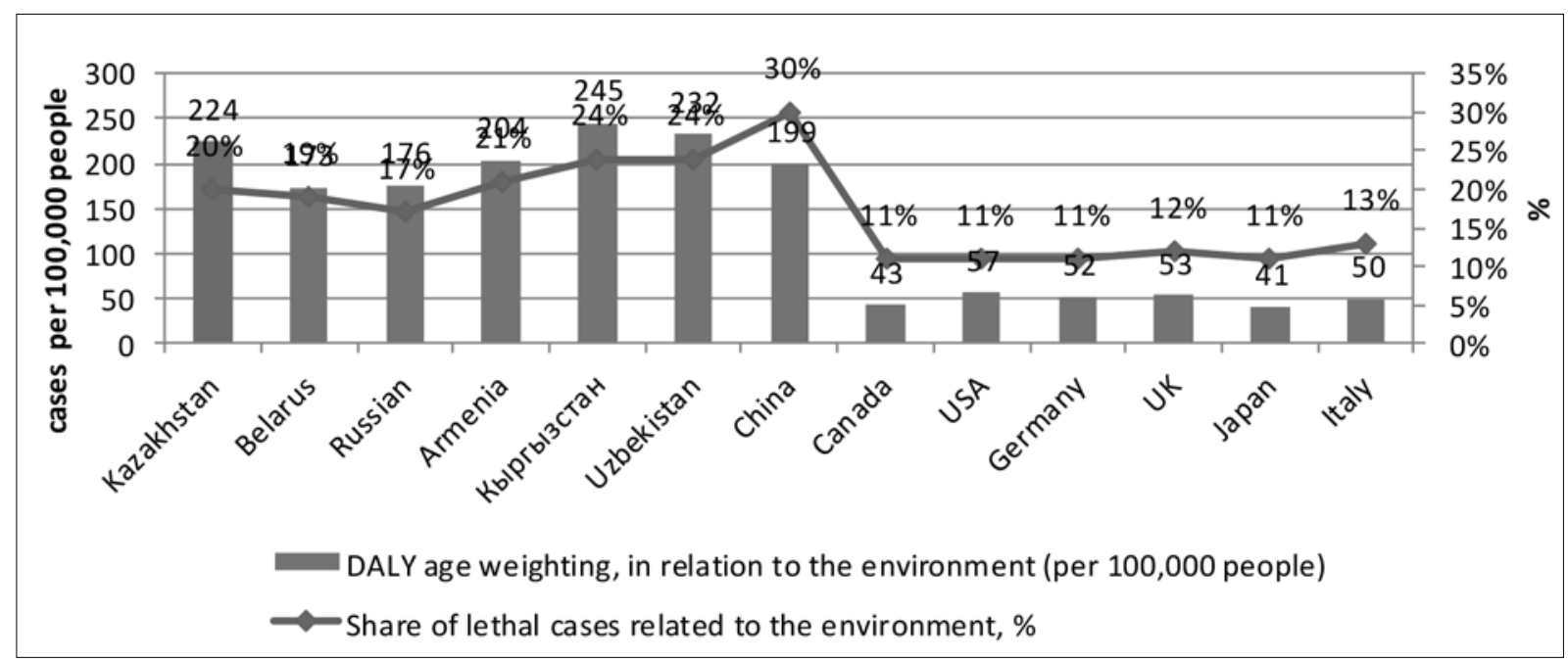

Figure 6. Total mortality due to the state of the environment in the Republic of Kazakhstan and some other countries (according to 2012 data) ${ }^{1}$.

Source: Compiled by autors.

According to WHO, in Kazakhstan, almost 24,996 deaths from 31,265 cases related to environmental factors are caused by non-communicable diseases such as stroke, coronary heart disease, oncology, and chronic respiratory diseases.

The mortality rate of the rural Kazakhstani population decreased from 789.78 cases per 100,000 rural population to 698.5 cases in 2012-2016. At the same time, the mortality structure of the rural population has not changed significantly. The main cause of death in the rural population was diseases of the circulatory system: in 2016, the figure was 138.62 cases per 100,000 rural population. Respiratory diseases are in the second place and oncology occupies the third place (Fig. 7).

1 Preventing disease through healthy environments: a global assessment of the burden of disease from environmental risks. 


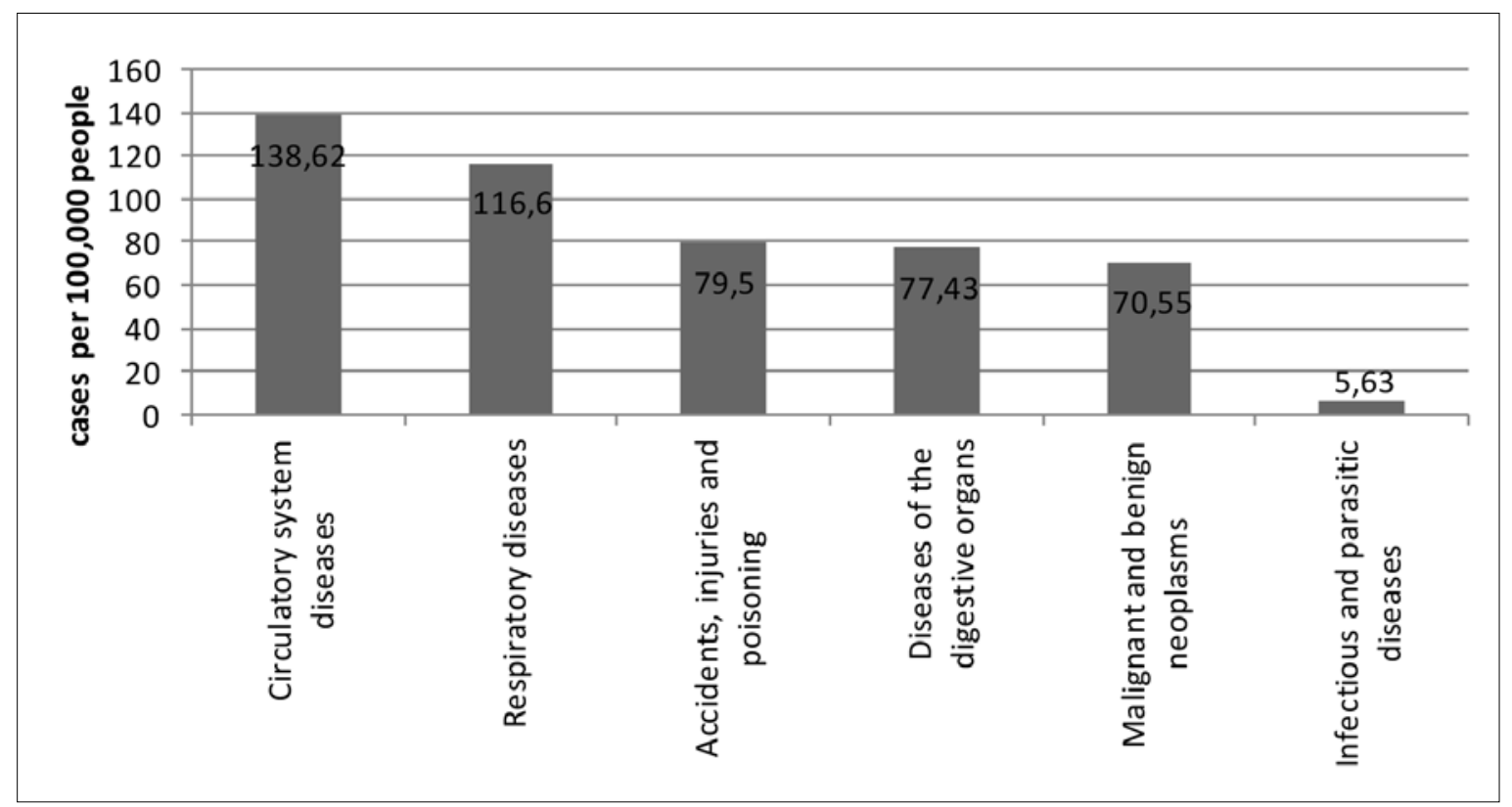

Figure 7. The mortality structure of the Kazakhstani rural population in 2016.

Source: Compiled by autors.

According to the WHO, the indicator of diseases caused by the state of the environment in the Republic of Kazakhstan is much higher than in Russia, Armenia, Belarus, and China (Fig. 8).

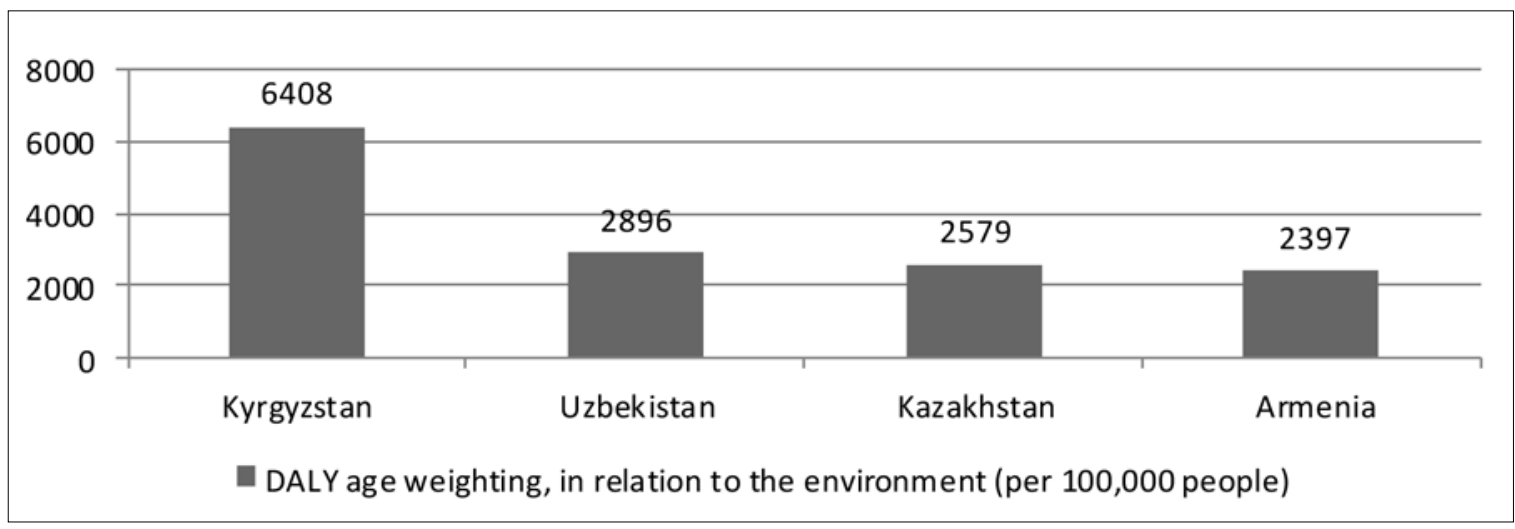

Figure 7. The burden of diseases caused by the state of the environment in the Republic of Kazakhstan and some other countries in 2012.

Source: Compiled by autors.

The incidence among the rural population in the Republic of Kazakhstan is steadily increasing. For example, this indicator increased by $9.6 \%$ for 2012-2016 (Table 1 ). 
Table 1. The incidence of the Kazakhstani rural population in 2012-2016, the number of cases per 100,000 people

\begin{tabular}{|c|c|c|c|c|c|c|c|}
\hline \multirow[t]{2}{*}{ Indicator } & \multirow[t]{2}{*}{2012} & \multirow[t]{2}{*}{2013} & \multirow[t]{2}{*}{2014} & \multirow[t]{2}{*}{2015} & \multirow[t]{2}{*}{2016} & \multicolumn{2}{|c|}{$\begin{array}{c}\text { Changes } \\
2016 / 2012\end{array}$} \\
\hline & & & & & & $+/-$ & $\%$ \\
\hline The number of diseases recorded for the first time in life & $4,3150.4$ & $42,720.9$ & $4,1632.6$ & $44,081.5$ & 47,305 & 4154,6 & $9.6 \%$ \\
\hline Infectious and parasitic diseases & 867.5 & 841.8 & 801.6 & 816.4 & 902.5 & 35 & $4.0 \%$ \\
\hline Neoplasms & 235.3 & 226.4 & 258.6 & 294.4 & 325.8 & 90.5 & $38.5 \%$ \\
\hline Circulatory system diseases & $2,290.2$ & $2,222.4$ & $2,300.6$ & $2,306.6$ & 2,408 & 117.8 & $5.1 \%$ \\
\hline Diseases characterized by elevated blood pressure & $1,181.4$ & $1,178.2$ & $1,196.2$ & $1,197.5$ & $1,242.1$ & 60.7 & $5.1 \%$ \\
\hline CHD & 488.6 & 468.6 & 481 & 452.6 & 445.3 & -43.3 & $-8.9 \%$ \\
\hline Acute myocardial infarction & 42.7 & 41.6 & 46.8 & 48 & 53.7 & 11 & $25.8 \%$ \\
\hline Cerebrovascular disease & 141.5 & 139.8 & 149.1 & 195 & 248.2 & 106.7 & $75.4 \%$ \\
\hline Respiratory diseases & $18,798.8$ & $1,9116.8$ & $1,8267.1$ & $19,010.1$ & $20,668.9$ & $1,870.1$ & $9.9 \%$ \\
\hline Asthma & 36.7 & 40.5 & 45.4 & 49.3 & 59 & 22.3 & $60.8 \%$ \\
\hline Diseases of the genitourinary system & $2,969.9$ & $2,842.2$ & $2,832.1$ & $3,231.4$ & $3,530.9$ & 561 & $18.9 \%$ \\
\hline Congenital anomalies (malformations) & 125.3 & 120.8 & 120.9 & 186.2 & 221.4 & 96.1 & $76.7 \%$ \\
\hline
\end{tabular}

Source: Compiled by authors

Diseases of the respiratory system are widespread in the Kazakhstani rural population. They account for $43.5 \%$ of registered patients with a diagnosis established for the first time in their lives.

The incidence of brain diseases caused by pathological changes in cerebral vessels and impaired cerebral circulation has significantly increased. The burden of cerebrovascular diseases among the rural population of the Republic of Kazakhstan increased by $75.4 \%$ and amounted to 248.2 cases per 100,000 rural residents during the period.

Cases of asthma also increased (+60.8\%). The main cause of asthma is a genetic predisposition. However, recently, the development and aggravation of this disease are also explained by the influence of various environmental factors. For example, air pollution induces oxidative stress, leading to inflammatory reactions in the airways and bronchial hyperresponsiveness.

A significant increase $(+76.7 \%)$ of congenital anomalies was noted among the rural population of Kazakhstan. Congenital anomalies include chromosomal conditions, such as Edward syndrome, and non-chromosomal conditions, such as various congenital organ defects. Many studies show that there is a stable connection between prenatal exposure to pesticides, organic solvents, air pollution, and congenital heart diseases, as well as between the effects of certain chemicals that destroy the endocrine system and the development of urinary tract malformations.

Thus, environmental pollution caused by emissions of greenhouse gases, enteric fermentation, emissions from manure storage and distribution systems, plant debris, as well as an increase in pesticide load, adversely affect the health of the population in the agricultural areas of the country.

\section{Discussion}

Improving the environment for health can make an important contribution to achieving the goals of the country's sustainable agricultural development. Many of these goals are closely related to environmental and social determinants.

Experts identify several approaches that can reduce the burden of diseases caused by the low ecology of agricultural production and promote a healthier lifestyle. 
The first approach requires reducing the risk of pesticide use. Now, chemical products remain the most widely used plant protection products in the region. Many of these substances are extremely toxic. In their application, farmers must work under special conditions and use personal protective equipment, which is unattainable for Kazakhstani farmers.

In May 2001, Kazakhstan signed the Stockholm Convention on POPs and in 2007, became a party to it, ratifying the Convention by the Law RF No. 259-III (2007).

To fulfill its obligations, the Republic of Kazakhstan has developed a National Implementation Plan for the Stockholm Convention on POPs for 2015-2028 (National Implementation Plan for the Republic of Kazakhstan, 2014). This document contains all the necessary elements reflected in the Guidance for Developing a National Implementation Plan for the Stockholm Convention on POPs. At the same time, international experts point out some problems of the National Plan, such as the lack of a mechanism for the process of consultative interaction between stakeholders, the lack of a technical infrastructure for measuring and analyzing alternatives to POPs, as well as for managing and destroying them. Also, the participation of the agricultural sector in the implementation of the National Implementation Plan is not clearly defined. Moreover, in the process of implementation of the Stockholm Convention, the Republic of Kazakhstan faced a number of difficulties caused by insufficient resource provision, gaps in the regulatory framework, the lack of intersectoral cooperation and poor coordination between government agencies, insufficient training of specialists in this field, etc.

According to market experts, there is much concern about the estimating emissions of POPs in Kazakhstan because nowadays, the system for regular monitoring of POPs does not exist in the country. The state enterprise Kazgidromet monitors the state of the environment. However, this organization does not monitor POPs throughout the Republic of Kazakhstan.

According to the Environmental Code of the Republic of Kazakhstan, nature users are obliged to carry out environmental monitoring, which includes production monitoring. However, the list of substances for environmental monitoring is limited and does not include POPs.

An important problem is the inappropriate use of equipment for identifying POPs. According to G. Maikenova, expert of the UNDP project, its main reason is the lack of regulatory bases, as well as the lack of qualified workers.

To solve the priority problems in the use of POPs in agriculture, it is necessary to make an inventory of the burial grounds and quantify the stored pesticides, recalibrate and store POPs in an environmentally safe way in special storage facilities for subsequent destruction.

Another approach to reducing environmental risks requires reducing greenhouse gas emissions in the agriculture of the Republic of Kazakhstan. According to studies by the European Bank for Reconstruction and Development and by the Food and Agriculture Organization of the United Nations, targeted investments can significantly reduce these emissions. Experts say that an investment of $\$ 2.3$ billion in the agro-food sector of Kazakhstan will reduce $\mathrm{CO} 2$ emissions by $30 \%$.

Experts point out that improving pastureland, saving and precision farming contributes to reducing emissions. The same analysis from the point of view of adaptation to climate change shows that drip irrigation is the best way to improve water availability and agricultural production.

Experts estimate that pasture improvement technologies (for example, planting saxaul on desert and semidesert pastures; producing roughage by sowing perennial grass species on fallow lands; irrigation of desert, steppe and meadow-steppe pastures where it can be applied) have the highest potential for greenhouse gases mitigation (57\% of the total) due to the substantial removal of soil carbon. Improved pastures make it possible to increase agricultural productivity by increasing the yield of hay from $0.3 \mathrm{t} / \mathrm{ha}$ to $0.9 \mathrm{t} / \mathrm{ha}$, and, under certain 
conditions, contribute to the prevention of land degradation.

According to experts, the potential of saving agriculture in the Republic of Kazakhstan is used by $36 \%$ and covers an area of 2.6 million hectares. The area of potential introduction of conservation agriculture in the Republic of Kazakhstan is estimated at 7.2 million hectares. It represents $40 \%$ of the total area under crops for grain, oil, and legumes. Experts believe that the potential reduction in greenhouse gas emissions from the use of conservation agriculture is 2.3 million tons of $\mathrm{CO} 2$ equivalent per year.

The current level of implementation of the precision farming technology in the Republic of Kazakhstan is $17 \%$ of the estimated potential. According to S. Nukeshev, dean of the Technical Faculty of S. Seifullin Kazakh AgroTechnical University, first of all, the introduction of new technologies (parallel driving, differential fertilization of fertilizers, herbicides, yield monitoring) is necessary for crop production. The development of precision farming in northern Kazakhstan (forecasting optimal terms for sowing, fertilizing, weed control, etc.) will reduce up to 122 thousand tons of $\mathrm{CO} 2$ equivalent/year.

Thus, the above measures aimed to reduce agricultural pollution of the environment, will reduce the incidence and improve the living standards of Kazakhstan.

\section{Conclusion}

The following conclusions were made based on the results of the study:

Agricultural pollution caused by greenhouse gas emissions, including emissions from livestock and crop production and the pesticide load on land resources, has been showing steady growth for five years.

The enteric fermentation, as well as manure collection, storage and distribution system, make up the largest proportion of agricultural pollution.

The application of pesticides and other chemical plant protection products increased with the reduction of agricultural land. As a result, the pesticidal load increased by 1.7 times.

The growth of agricultural pollution negatively affects public health and living standards. The Republic of Kazakhstan is ahead of high-income countries, as well as Belarus and Russia, in terms of mortality rates and the burden of diseases caused by the state of the environment.

The incidence is steadily increasing among the rural population. The number of cases of congenital anomalies and the incidence of cerebrovascular diseases and asthma are increasing especially rapidly.

A set of measures is needed to reduce the burden of diseases caused by environmental pollution. These measures should be aimed at reducing the risk of pesticide use and greenhouse gas emissions in the agriculture of the Republic of Kazakhstan.

\section{References}

Ahada, C.P.S., Suthar, S. (2018). Groundwater nitrate contamination and associated human health risk assessment in southern districts of Punjab, India. Environmental Science and Pollution Research, 25(25), 25336-25347.

Alimaev, I.I. (2008). The impact of livestock grazing on soils and vegetation around settlements in Southeast Kazakhstan. The Socioeconomic Causes and Consequences of Desertification in Central Asia, 81-112.

Analytical Environmental Agency "Greenwomen". (2018). Review of the implementation of the obligations of the Republic of Kazakhstan on the Stockholm Convention on POPs. Kazakhstan. Retrieved from: http://www.greenwomen.kz/pdf/pops_ru_2018.pdf 
Boxall, A.B.A. (2012). New and emerging water pollutants arising from agriculture. Paris, OECD. Retrieved from: http://www.oecd. org/tad/sustainable-agriculture/49848768.pdf

Chen, H., Huo, Z., Dai, X., Ma, S., Xu, X., Huang, G. (2018). Impact of agricultural water-saving practices on regional evapotranspiration: The role of groundwater in sustainable agriculture in arid and semi-arid areas. Agricultural and Forest Meteorology, 263, 156-168.

Dörre, A., Borchardt, P. (2012). Changing systems, changing effects-pasture utilization in the post-Soviet transition: Case studies from southwestern Kyrgyzstan. Mountain Research and Development, 32(3), 313-323.

FAO. (2018). Globally Important Agricultural Heritage Systems (GIAHS). Combining agricultural biodiversity, resilient ecosystems, traditional farming practices and cultural identity. Rome, Italy.

FAOSTAT. (n.d.). Retrieved from: http://www.fao.org/faostat/ru/\#data/GE

FLERMONECA. (2015). Regional Environmental Centre for Central Asia, Environmental Agency of Austria, Zoi Environment Network. The State of the Environment in Central Asia: Illustrations of Selected Environmental Themes and Indicators. Retrieved from: https://archive.zoinet.org/web/sites/\%20default/files/publications/SOE-regional-eng.pdf

Gintzburger, G., Le Houérou, H.N., Toderich, K.N. (2005). The steppes of Middle Asia: Post-1991 agricultural and rangeland adjustment. Arid Land Research and Management,19(3), 215-239.

Law of the Republic of Kazakhstan No. 259-III. (June 7, 2007). "On Ratification of the Stockholm Convention on Persistent Organic Pollutants”. Retrieved from: https://online.zakon.kz/Document/?doc_id=30106963

Mateo-Sagasta, J., Raschid-Sally, L., and Thebo, A. (2015). Global wastewater and sludge production, treatment and use. In P. Drechsel, M. Qadir and D. Wichelns, eds, Wastewater - economic asset in an urbanizing world. Springer. The Netherlands.

Menta, C., Conti, F.D., Pinto, S., Bodini, A. (2018). Soil Biological Quality index (QBS-ar): 15 years of application at global scale. Ecological Indicators, 85, 773-780.

National plan for fulfilling the obligations of the Republic of Kazakhstan under the Stockholm Convention on Persistent Organic Pollutants for 2015 - 2028. (2014). Ministry of Energy of the Republic of Kazakhstan. Retrieved from: https://is.gd/sw3I7A

OECD (2016b). Multi-dimensional Review of Kazakhstan: Volume 1. Initial Assessment. OECD. Development Pathways. OECD Publishing. Paris.

OECD, (2016a). Education at a Glance 2016 - Indicators. Retrieved from: http://www.oecd.org/education/skills-beyond-school/education-at-a-glance-2016-indicators.htm

Oetjen, K., Blotevogel, J., Borch, T., Ranville, J.F., Higgins, C.P. (2018). Simulation of a hydraulic fracturing wastewater surface spill on agricultural soil. Science of the Total Environment, 645, 229-234.

Ospanova, S. (2014). Assessing Kazakhstan's policy and institutional framework for a green economy. IIED Country Report. London. Retrieved from: http://pubs.iied.org/pdfs/16559IIED.pdf

Prüss-Ustün, A., Wolf, J., Corvalán, C., Bos, R., and Neira, M. (2016). Preventing disease through healthy environments a global assessment of the burden of disease from environmental risks. Retrieved from: http://apps.who.int/iris/bitstream/10665/204585/1/9789241565196 eng.pdf?ua $=1$

Robinson, S., Jamsranjav, C., Gillin, K. (2017). Pastoral property rights in Central Asia. Factors and actors driving the reform agenda. Etudes Rurales, 200(2), 220-253.

Sato, T., Qadir, M., Yamamoto, S., Endo. T., and Zahoor, M. (2013). Global, regional, and country level need for data on wastewater generation, treatment, and use. Agricultural Water Management, 130, 1-13.

Seilkhan, A.S., Mizadinov, R.A.-A., Mizadinov, I.R., Kizdarbekova, M.A. (2016). Degradation of lands in Central Asia. 16th International Multidisciplinary Scientific GeoConference SGEM, June 28-July 6, 5(2), 195-208.

Serio, F., Miglietta, P.P., Lamastra, L., Ficocelli, S., Intini, F., De Leo, F., De Donno, A. (2018). Groundwater nitrate contamination and agricultural land use: A grey water footprint perspective in Southern Apulia Region. Italy. Science of the Total Environment, 645, $1425-1431$

Shaaban, M., Van Zwieten, L., Bashir, S., Younas, A., Núñez-Delgado, A., Chhajro, M.A., Kubar, K.A., Ali, U., Rana, M.S., Mehmood, M.A., Hu, R. (2018). A concise review of biochar application to agricultural soils to improve soil conditions and fight pollution. Journal of Environmental Management, 228, 429-440. 
Shin, W.-J., Ryu, J.-S., Lee, K.-S., Park, Y. (2015). Identification of anthropogenic pollution sources in urbanized streams using several isotopes. Ecological Earth Sciences, 73(12), 8311-8324.

Tanentzap, A.J., Lamb, A., Walker, S., Farmer, A. (2015). Resolving Conflicts between Agriculture and the Natural Environment. PLOS. Retrieved from: https://goo.gl/rLARnk

Wen, Y., Schoups, G., van de Giesen, N. (2017). Organic pollution of rivers: Combined threats of urbanization, livestock farming and global climate change. Scientific Reports, 7. Retrieved from: https://www.nature.com/articles/srep43289

Madina Amangeldinovna AITKAZINA, PhD

ORCID ID: orcid.org/0000-0002-8410-0900

Ermek NURMAGANBET

ORCID ID: orcid.org/0000-0001-6248-2429

Samal SYRLYBEKKYZY

ORCID ID: orcid.org/0000-0002-0260-0611

Symbat KOIBAKOVA

ORCID ID: orcid.org/0000-0002-7866-2341

Ainur Erbulatovna ZHIDEBAYEVA

ORCID ID: orcid.org/0000-0002-1217-5305

\section{M.Zh. AUBAKIROV}

ORCID ID: orcid.org/0000-0002-5688-2634

This work is licensed under the Creative Commons Attribution International License (CC BY). http://creativecommons.org/licenses/by/4.0/ 